\title{
Correlation of growth hormone secretion during pregnancy with circulating prolactin in rats
}

\author{
G. A. Jahn ${ }^{1}$, A. M. Rastrilla ${ }^{2}$ and R. P. Deis ${ }^{1}{ }^{1}$ \\ ${ }^{1}$ Laboratorio de Reproduccion y Lactancia, CRICYT-CONICET, Casilla de Correos 855, 5500 \\ Mendoza, Argentina; and ${ }^{2}$ Facultad de Bioquimica, Quimica y Farmacia, Universidad Nacional de \\ San Luis, San Luis, Argentina
}

\begin{abstract}
Growth hormone $(\mathrm{GH})$ concentrations were measured throughout pregnancy in rats. The effects of surgical stress, ovariectomy, and treatments with the antiprogesterone mifepristone (RU 486) or the antioestrogen tamoxifen on serum $\mathrm{GH}$, progesterone and prolactin were studied. GH concentrations were low during the first 18 days of pregnancy, except on the morning of day 5, and increased progressively from day 19 reaching peak values on the mornings of days 21 and 22. Thereafter $\mathrm{GH}$ concentrations decreased progressively, reaching very low values at $24.00 \mathrm{~h}$ on day 22 , in parallel with a rise in serum prolactin concentrations. Surgical stress, performed at $12.00 \mathrm{~h}$ on day 20 of pregnancy, diminished serum GH concentrations 10 min later, but these returned to values similar to those of the non-operated rats 1-24 h later. Surgical stress did not modify serum prolactin concentrations at any time. Ovariectomy performed on the morning of day 19 produced the expected fall in serum progesterone and a rise in prolactin which lasted until the night of day 20 . Serum $\mathrm{GH}$ concentrations were significantly diminished with respect to controls on day 20 and the morning of day 21 and then increased. Treatment with mifepristone on day 19 produced a simultaneous rise in serum prolactin and a fall in serum progesterone and $\mathrm{GH}$ by $08.00 \mathrm{~h}$ on day 21 . Treatment with tamoxifen on days 3 and 4, or given daily from day 17 onwards did not modify prolactin concentrations but diminished serum GH concentrations at 08.00 on day 5 and on days 19-22, with the exception of a peak on day $22(08.00 \mathrm{~h})$. Tamoxifen also decreased serum progesterone concentrations. These results show that pregnant rats have a reduced capacity of response to stress in terms of changes in $\mathrm{GH}$ and prolactin secretion. There are high serum concentrations of $\mathrm{GH}$ at the end of pregnancy. The regulation of $\mathrm{GH}$ secretion at this time is different from that of prolactin and does not seem to depend on the fall in progesterone concentrations. However, serum $\mathrm{GH}$ concentrations seem to be inversely correlated with serum prolactin concentrations, as they tended to fall after increases in prolactin above basal concentrations. Oestrogen may also have a stimulatory role on $\mathrm{GH}$ since administration of an anti-oestrogen also resulted in a fall in $\mathrm{GH}$ concentrations in spite of reduced prolactin secretion.
\end{abstract}

\section{Introduction}

Regulation of growth hormone (GH) secretion shows some similarities to and some differences from prolactin secretion. $\mathrm{GH}$ is secreted in an ultradian fashion as several daily peaks, and there is a marked sexual dimorphism which is caused mainly by sex steroids (Tannenbaum and Martin, 1976; Eden, 1979; Jansson et al., 1984, 1985). GH secretion is stimulated by GH-releasing hormone, inhibited by somatostatin, which also inhibits prolactin, and GH and prolactin are stimulated by oestrogens (Jansson et al., 1985; Hall et al., 1986). Glucocorticoids have dual actions on GH release and inhibit prolactin release (Leung et al.,

${ }^{*}$ Correspondence.

Received 20 May 1992.
1980; Nakagawa et al., 1987a, b). Both hormones are also modulated by neurotransmitters; serotonin is mainly stimulatory for both (Martin et al., 1978; Willoughby et al., 1987), whereas catecholamines have opposite effects on $\mathrm{GH}$ and prolactin secretion (Martin et al., 1978; Eden et al., 1979; Willoughby and Day, 1981; Crowley et al., 1982). Stress also has opposite effects, stimulating prolactin release and inhibiting GH (Schalch and Reichlin, 1966; Takahashi $e t$ al., 1971; Krulich et al., 1974; Terry et al., 1976; Eden, 1978). Finally, the suckling stimulus induces secretion of prolactin and $\mathrm{GH}$, although the latter only in a transient manner (Sar and Meites, 1969; Saunders et al., 1976; Nagy et al., 1986).

In rats, the fall in circulating progesterone at the end of pregnancy is followed by an increase in serum prolactin (Vermouth and Deis, 1972, 1974; Bussmann and Deis, 1979) which is 
mediated by adrenergic but not serotonergic pathways (Jahn and Deis, 1987, 1988, 1991). In the present study, we investigated the circulating concentrations of $\mathrm{GH}$ throughout pregnancy in rats and the regulation of GH by stress and gonadal hormones. Previous studies performed on selected days of pregnancy (Saunders et al., 1976; Klindt et al., 1981; Carlsson et al., 1990) showed that there is an increase in GH secretion in the last days of pregnancy. We, therefore, studied the profile of GH secretion at different times on days 4-6, 11-13 and 18-22 of pregnancy. We also investigated whether procedures known to advance prolactin secretion through a fall in or blockade of progesterone (such as ovariectomy or treatment with the antiprogesterone mifepristone) could modify $\mathrm{GH}$ secretion at the end of pregnancy. In addition, we studied the effect of tamoxifen administration, as oestrogens appear to stimulate $\mathrm{GH}$ secretion (Simard et al., 1986; Ho et al., 1987). Some of these results have been presented in abstract form (Jahn et al., 1987).

\section{Materials and Methods}

\section{Animals}

Virgin female rats, three to four months old (200-220 g) bred in our laboratory and originally of the Wistar strain, were used. The rats were kept in a light (lights on 06.00-20.00 h)- and temperature $\left(22-24^{\circ} \mathrm{C}\right.$ )-controlled room; rat chow (Cargill, Buenos Aires and Nutric, Cordoba) and tap water were available ad libitum. Vaginal smears were taken daily. Rats were caged individually with fertile males on the night of prooestrus, and the presence of spermatozoa was checked in the vaginal smear the following morning. This day was designated day 1 of pregnancy. In our laboratory, rats usually give birth on day 23. All the rats were handled daily, to minimize the effect of handling stress. The experiments were performed in accordance with the NIH Guide for the Care and Use of Laboratory Animals (NIH publication No. 86-23, revised 1985).

\section{Experimental procedures}

To study GH concentrations throughout pregnancy, serum samples were obtained after decapitation or cardiac puncture of conscious animals at $08.00,12.00,16.00,20.00$ and $24.00 \mathrm{~h}$ on days $4,5,6,11,12,13,18,19,20,21$ and 22 of pregnancy. Rats were bled once by cardiac puncture on days $4-6$ or 11-13 and the second time after decapitation on days 19 to 22 . All the groups sampled on days $4-6$ and 11-13 included samples from decapitated rats, whose hormone concentration did not differ from the samples obtained by cardiac puncture. These samples can be considered as from unstressed rats, since they were obtained within $15 \mathrm{~s}$ and serum prolactin values obtained in these rats were not different from those obtained in decapitated rats from the same experimental groups. Blood was allowed to clot at room temperature; the serum was separated and stored frozen at $-30^{\circ} \mathrm{C}$ until assayed for $\mathrm{GH}$ and prolactin.

\section{Surgical procedures}

Ovariectomy was performed through bilateral incisions under ether anaesthesia between 08.00 and $09.00 \mathrm{~h}$ on day 19 of pregnancy. Groups of intact or sham-operated rats were used as controls, and since the hormone concentrations of both groups did not differ, they were considered as one group for statistical evaluation and expression of results.

To determine the effect of the surgical stress on serum $\mathrm{GH}$ and prolactin concentrations, a group of daily handled pregnant rats were sham operated (laparotomized) at $12.00 \mathrm{~h}$ on day 20 of pregnancy under ether anaesthesia. Groups of rats were decapitated $10 \mathrm{~min}, 1 \mathrm{~h}, 4 \mathrm{~h}$ and $24 \mathrm{~h}$ after surgery and blood was obtained for $\mathrm{GH}$ and prolactin determinations. The values obtained were compared with those of intact pregnant rats obtained at the same times of day.

\section{Drug treatments}

Mifepristone (RU 38486, donated by Roussel-Uclaf, Romainville, France) dissolved in sunflower seed oil $\left(2 \mathrm{gl}^{-1}\right)$ was injected s.c. at a dose of $2 \mathrm{mg} \mathrm{kg}^{-1}$ at $08.00 \mathrm{~h}$ on day 19 of pregnancy.

Tamoxifen (ICI 46474, donated by Gador, Buenos Aires) was dissolved in $0.5 \%$ Tween $80\left(50 \mathrm{mg} \mathrm{l}^{-1}\right)$ and given per os at a dose of $0.5 \mathrm{mg} \mathrm{kg}^{-1}$ to a group of rats at 08.00 and $18.00 \mathrm{~h}$ on days 3 and 4 of gestation. The rats were decapitated at $08.00 \mathrm{~h}$ on day 5 and trunk blood collected for hormone determinations.

For the experiments at the end of pregnancy, tamoxifen was dissolved in sunflower seed oil $\left(1 \mathrm{gl}^{-1}\right)$ and injected daily at a dose of $200 \mu \mathrm{g}$ per rat at $09.00 \mathrm{~h}$ from day 17 of pregnancy until the morning the rats were killed.

Blood samples were obtained from groups of 8-10 animals subjected to the different treatments at $12.00,16.00$ or $20.00 \mathrm{~h}$ on day 19 and $08.00,12.00,16.00$ or $20.00 \mathrm{~h}$ on days 20,21 or 22. The first sample was obtained by cardiac puncture on days 19 or 20 and the second after decapitation at least $36 \mathrm{~h}$ later. In the mifepristone-treated rats, the last sample was obtained at $08.00 \mathrm{~h}$ on day 22 as by this time most of these animals had already given birth.

\section{Prolactin, progesterone and $\mathrm{GH}$ determinations}

Prolactin and $\mathrm{GH}$ were measured by double antibody radioimmunoassays using materials generously provided by the NIADDK (S. Raiti, NIADDK Rat Pituitary Hormone Distribution Program). The hormones were radio-iodinated using the chloramine $T$ method and purified by passage through Sephadex G75. The results were expressed in terms of the rat prolactin RP-3 and rat GH RP-2 standard preparations. Assay sensitivity for both hormones was $0.5 \mathrm{ng} \mathrm{ml}^{-1}$ serum and the inter- and intra-assay coefficients of variation were less than $10 \%$.

Serum progesterone was measured using a radioimmunoassay developed in our laboratory (Bussmann and Deis, 1979) with an antiserum raised in rabbits against progesterone-11BSA conjugate. Assay sensitivity was less than $5 \mathrm{ng} \mathrm{ml}^{-1}$ serum and the inter- and intra-assay coefficients of variation were less than $10 \%$.

\section{Statistical analysis}

Statistical analysis was performed using one- or two-way analysis of variance followed by the least significant difference 


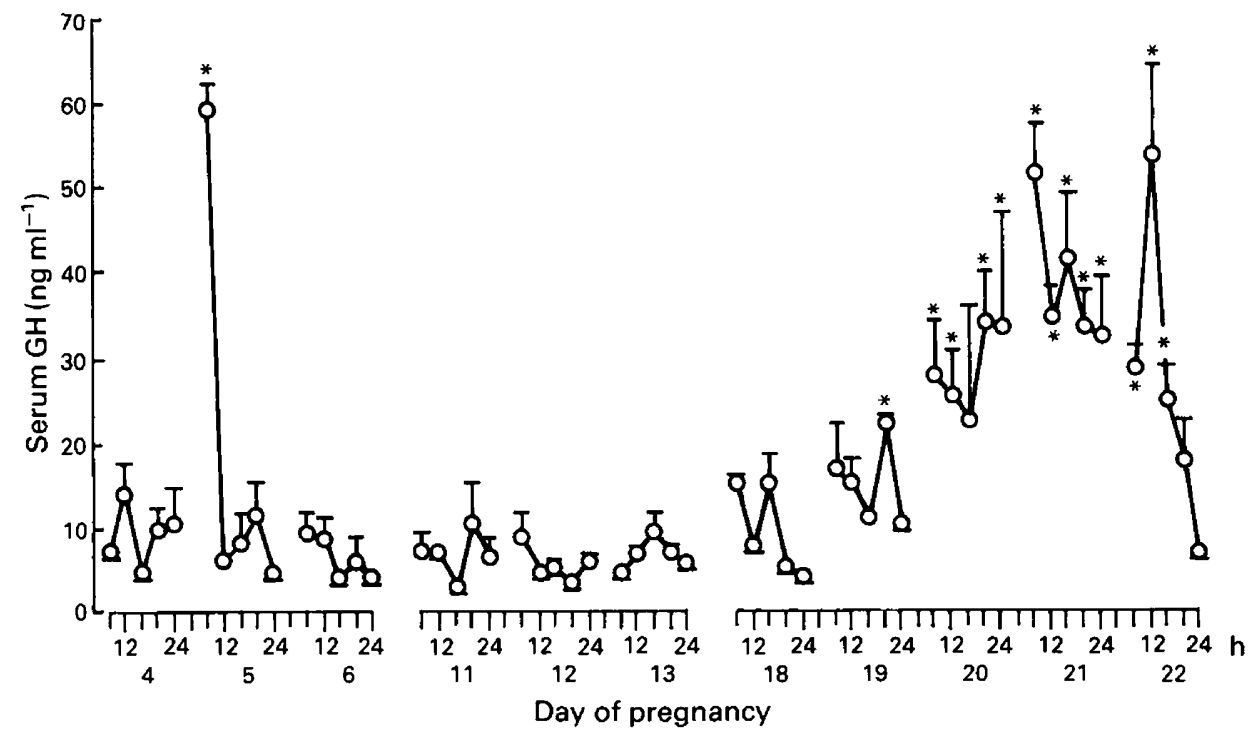

Fig. 1. Concentrations of growth hormone in serum during pregnancy in rats. Results are the means \pm SEM of six determinations for days $4-18$ and of $10-15$ on days $19-22$. *Significantly different $(P<0.05$ ) from the means of days $4-18$ (excluding day $5,08.00 \mathrm{~h}$ ).

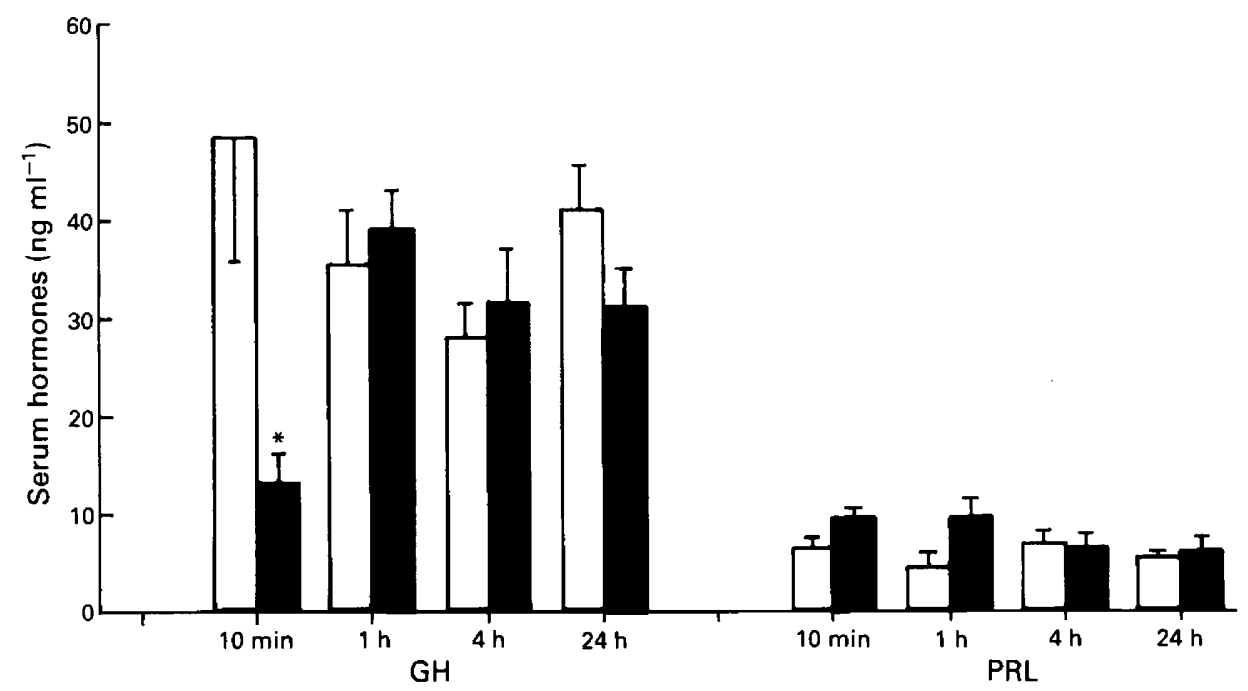

Fig. 2. Effect of sham surgery (laparotomy) under ether anaesthesia performed on rats at $12.00 \mathrm{~h}$ on day 20 of pregnancy on serum GH and prolactin (PRL) concentrations ( $\boldsymbol{\square}$ ) at various times after surgery. Comparison with serum hormone concentrations in intact rats $(\square)$ sampled at the same times. Results are expressed as means \pm SEM of groups of five to six rats per sampling time. ${ }^{*}$ Significantly different $(P<0.05)$ from control results.

between means test when more than two experimental groups were compared or by Duncan's multiple range test for analysis of the significance between different groups during pregnancy or after surgery (Snedecor and Cochran, 1967).

\section{Results}

Effect of surgical stress on serum GH and prolactin concentrations in pregnant rats

To ascertain the effect of surgery alone on serum GH and prolactin, groups of 5-6 rats were bled by decapitation $10 \mathrm{~min}$,
I h, $4 \mathrm{~h}$ and $24 \mathrm{~h}$ after sham surgery (laparotomy) under ether anaesthesia performed at $12.00 \mathrm{~h}$ on day 20 of pregnancy, when serum GH concentrations are high (Fig. 1) and compared with values for non-operated rats decapitated at the same times. Ten minutes after surgery there was a significant decrease in serum $\mathrm{GH}$ concentrations, whereas $\mathrm{I}-24 \mathrm{~h}$ after surgery, values were not different from the non-operated group (Fig. 2). There were no significant changes in serum prolactin concentrations at any of the times studied (Fig. 2). As blood samples in the ovariectomized rats were taken from $4 \mathrm{~h}$ after surgery, the observed changes in serum $\mathrm{GH}$ and prolactin values were due to the different treatments and not to surgical stress. 
Table 1. Serum GH, prolactin and progesterone concentrations (ng $\mathrm{ml}^{-1}$ ) in rats on days $19-22$ of pregnancy. Effects of ovariectomy, treatment with mifepristone or tamoxifen

\begin{tabular}{|c|c|c|c|c|c|c|}
\hline \multirow{3}{*}{$\begin{array}{l}\text { Day of gestation } \\
\text { and time of day } \\
\text { when samples } \\
\text { were taken }\end{array}$} & \multicolumn{6}{|c|}{ Treatments } \\
\hline & \multicolumn{3}{|c|}{ Controls } & \multicolumn{3}{|c|}{ Ovariectomy } \\
\hline & $\mathrm{GH}$ & Prolactin & Progesterone & $\mathrm{GH}$ & Prolactin & Progesterone \\
\hline \multicolumn{7}{|l|}{ Day 19} \\
\hline $12.00 \mathrm{~h}$ & $15.7 \pm 1.6$ & $8.0 \pm 1.8$ & $64.3 \pm 3.1$ & $10.4 \pm 1.6$ & $10.6 \pm 2.2$ & $17.7 \pm 2.0^{*}$ \\
\hline $16.00 \mathrm{~h}$ & $10.8 \pm 1.3$ & $5.6 \pm 1.0$ & $55.5 \pm 2.9$ & $16.8 \pm 1.6$ & $7.0 \pm 1.9$ & $13.7 \pm 3.4^{*}$ \\
\hline $20.00 \mathrm{~h}$ & $22.2 \pm 3.1$ & $3.3 \pm 0.2$ & $54.7 \pm 4.9$ & $11.1 \pm 1.3^{*}$ & $13.4 \pm 4.2^{*}$ & $7.6 \pm 1.0^{*}$ \\
\hline \multicolumn{7}{|l|}{ Day 20} \\
\hline $8.00 \mathrm{~h}$ & $28.0 \pm 7.0$ & $7.1 \pm 1.2$ & $62.1 \pm 4.3$ & $12.0 \pm 1.1^{*}$ & $24.5 \pm 2.5^{*}$ & $10.3 \pm 1.0^{*}$ \\
\hline $12.00 \mathrm{~h}$ & $32.2 \pm 6.0$ & $6.4 \pm 1.1$ & $46.6 \pm 3.8$ & $13.6 \pm 4.3^{*}$ & $28.2 \pm 7.2^{*}$ & $4.0 \pm 1.1^{*}$ \\
\hline $16.00 \mathrm{~h}$ & $27.8 \pm 3.6$ & $9.1 \pm 0.8$ & $70.3 \pm 3.0$ & $15.1 \pm 3.7^{*}$ & $21.4 \pm 6.2^{*}$ & $7.2 \pm 0.9^{*}$ \\
\hline $20.00 \mathrm{~h}$ & $30.1 \pm 4.8$ & $5.8 \pm 0.6$ & $61.5 \pm 5.6$ & $11.6 \pm 1.8^{*}$ & $12.5 \pm 1.0^{*}$ & $4.9 \pm 0.7^{*}$ \\
\hline \multicolumn{7}{|l|}{ Day 21} \\
\hline $8.00 \mathrm{~h}$ & $53.0 \pm 5.3$ & $7.5 \pm 0.5$ & $58.3 \pm 3.1$ & $10.7 \pm 1.1^{*}$ & $10.4 \pm 2.0$ & $7.6 \pm 1.3^{*}$ \\
\hline $12.00 \mathrm{~h}$ & $36.6 \pm 3.3$ & $5.4 \pm 0.6$ & $42.0 \pm 4.2$ & $34.2 \pm 6.7$ & $7.0 \pm 1.0$ & ND \\
\hline $16.00 \mathrm{~h}$ & $42.1 \pm 7.6$ & $7.6 \pm 0.8$ & $50.0 \pm 5.0$ & $49.5 \pm 13.8$ & $8.5 \pm 1.3$ & ND \\
\hline $20.00 \mathrm{~h}$ & $28.7 \pm 2.7$ & $5.7 \pm 0.5$ & $48.5 \pm 2.2$ & $30.6 \pm 9.3$ & $10.2 \pm 3.4$ & $14.2 \pm 0.5^{*}$ \\
\hline \multicolumn{7}{|l|}{ Day 22} \\
\hline $8.00 \mathrm{~h}$ & $29.2 \pm 2.1$ & $9.3 \pm 0.4$ & $41.2 \pm 7.6$ & $25.1 \pm 9.3$ & $12.5 \pm 4.2$ & $10.2 \pm 2.8^{*}$ \\
\hline $12.00 \mathrm{~h}$ & $54.0 \pm 11.0$ & $15.6 \pm 6.0$ & $23.3 \pm 4.7^{* *}$ & $24.4 \pm 7.1$ & $6.9 \pm 0.8$ & ND \\
\hline $16.00 \mathrm{~h}$ & $25.1 \pm 3.8^{* *}$ & $36.4 \pm 4.5^{* *}$ & $18.8 \pm 2.8^{* *}$ & $28.8 \pm 7.9$ & $8.1 \pm 1.2$ & ND \\
\hline \multirow[t]{3}{*}{$20.00 \mathrm{~h}$} & $12.7 \pm 1.5^{* *}$ & $22.4 \pm 6.4^{* *}$ & $12.8 \pm 2.1^{* *}$ & $21.2 \pm 4.6$ & $10.1 \pm 1.7^{*}$ & $7.6 \pm 1.8$ \\
\hline & \multicolumn{3}{|c|}{ Mifepristone } & \multicolumn{3}{|c|}{ Tamoxifen } \\
\hline & GH & Prolactin & Progesterone & $\mathrm{GH}$ & Prolactin & Progesterone \\
\hline \multicolumn{7}{|l|}{ Day 19} \\
\hline $12.00 \mathrm{~h}$ & $21.8 \pm 1.9$ & $6.6 \pm 1.2$ & $59.6 \pm 4.3$ & $15.1 \pm 2.2$ & $3.9 \pm 0.6$ & $43.0 \pm 2.9^{*}$ \\
\hline $16.00 \mathrm{~h}$ & $24.0 \pm 4.0^{*}$ & $3.2 \pm 0.8$ & $47.4 \pm 2.7$ & $11.7 \pm 2.7$ & $5.1 \pm 0.5$ & $50.8 \pm 3.4$ \\
\hline $20.00 \mathrm{~h}$ & $16.2 \pm \quad 5.5$ & $6.1 \pm 0.9$ & $37.5 \pm 4.6$ & $10.8 \pm 1.4^{*}$ & $3.9 \pm 0.5$ & $29.7 \pm 1.7^{*}$ \\
\hline \multicolumn{7}{|l|}{ Day 20} \\
\hline $8.00 \mathrm{~h}$ & $35.9 \pm 6.7$ & $6.9 \pm 0.9$ & $51.4 \pm 3.6$ & $4.9 \pm 0.7^{*}$ & $4.7 \pm 0.8$ & $32.2 \pm 2.0^{*}$ \\
\hline $12.00 \mathrm{~h}$ & $41.7 \pm 14.5$ & $7.4 \pm 0.6$ & $36.3 \pm 4.6^{*}$ & $17.7 \pm 3.0^{*}$ & $2.6 \pm 0.5$ & $29.2 \pm 2.9^{*}$ \\
\hline $16.00 \mathrm{~h}$ & $21.8 \pm 5.9$ & $12.5 \pm 3.6$ & $36.1 \pm 4.8^{*}$ & $12.6 \pm 2.4^{*}$ & $2.1 \pm 0.5^{*}$ & $53.1 \pm 3.8^{*}$ \\
\hline $20.00 \mathrm{~h}$ & $24.7 \pm 4.0$ & $6.0 \pm 1.0$ & $40.6 \pm 3.3$ & $9.7 \pm 1.6^{*}$ & $5.2 \pm 1.7$ & $30.1 \pm 6.7^{*}$ \\
\hline \multicolumn{7}{|l|}{ Day 21} \\
\hline $8.00 \mathrm{~h}$ & $12.8 \pm 2.2^{*}$ & $53.1 \pm 8.8^{*}$ & $25.3 \pm 4.1^{*}$ & $12.0 \pm 3.6^{*}$ & $4.4 \pm 1.4$ & $27.6 \pm 4.1^{*}$ \\
\hline $12.00 \mathrm{~h}$ & $16.4 \pm 4.4^{*}$ & $28.7 \pm 7.2^{*}$ & $13.7 \pm 3.1^{*}$ & $13.9 \pm 3.7^{*}$ & $5.5 \pm 1.2$ & $25.2 \pm 8.3^{*}$ \\
\hline $16.00 \mathrm{~h}$ & $8.3 \pm 2.2^{*}$ & $25.3 \pm 11.4^{*}$ & $8.8 \pm 2.1^{*}$ & $15.9 \pm 3.1^{*}$ & $6.5 \pm 1.2$ & $8.7 \pm 1.6^{*}$ \\
\hline $20.00 \mathrm{~h}$ & $6.0 \pm 1.6^{*}$ & $23.6 \pm 5.2^{*}$ & $12.8 \pm 1.8^{*}$ & $14.3 \pm 4.0^{*}$ & $14.6 \pm 8.5$ & $7.8 \pm 1.4^{*}$ \\
\hline \multicolumn{7}{|l|}{ Day 22} \\
\hline $8.00 \mathrm{~h}$ & $11.6 \pm 2.5^{*}$ & $34.4 \pm 8.4^{*}$ & $8.6 \pm 0.6^{*}$ & $21.1 \pm 5.0$ & $3.0 \pm 1.7$ & $15.9 \pm 3.1^{*}$ \\
\hline $12.00 \mathrm{~h}$ & Abortion & Abortion & Abortion & $25.6 \pm 7.5^{*}$ & $5.5 \pm 0.5$ & $10.9 \pm 4.5^{*}$ \\
\hline $16.00 \mathrm{~h}$ & & & & $25.8 \pm 6.2$ & $1.8 \pm 0.4^{*}$ & $7.4 \pm 1.3^{*}$ \\
\hline $20.00 \mathrm{~h}$ & & & & $4.8 \pm 0.9^{*}$ & $4.6 \pm 1.2^{*}$ & $7.2 \pm 0.6$ \\
\hline
\end{tabular}

Results are the means \pm SEM of 8-15 determinations at each time point.

${ }^{*} P<0.05$ compared with controls; ${ }^{* *} P<0.05$ compared with values on day 21 .

ND: not determined.

\section{Serum GH concentrations during pregnancy}

In the present study we have not attempted to study the ultradian rhythm that has been repeatedly described for GH secretion (Saunders et al., 1976; Klindt et al., 1981). Average values obtained in different rats sampled at the same hour are given and represent mean secretion of $\mathrm{GH}$. Serum $\mathrm{GH}$ concentrations remained below $20 \mathrm{ng} \mathrm{ml}^{-1}$ during days $4-6$ and $11-13$ of pregnancy, except on the morning of day $5(08.00 \mathrm{~h})$ when values increased significantly to $60 \mathrm{ng} \mathrm{ml}^{-1}$ (Fig. 1). Values were low on day 18, but from day 19 onwards, serum GH concentrations increased progressively, reaching concentrations as high as $53 \mathrm{ng} \mathrm{ml}^{-1}$ at $08.00 \mathrm{~h}$ on day 21 with a new peak at $12.00 \mathrm{~h}$ on day 22 , followed by a marked decrease during the afternoon, to a minimum of $10 \mathrm{ng} \mathrm{ml}^{-1}$ at midnight of day 22 , which was coincident with an increase in serum prolactin concentrations and a fall in progesterone (see Table 1). 
Effect of ovariectomy on serum concentrations of $G H$, prolactin and progesterone

Ovariectomy performed on day 19 changed the rhythm of serum GH secretion, decreasing the values with respect to controls at $20.00 \mathrm{~h}$ on day 19 , throughout day 20 and up to $08.00 \mathrm{~h}$ on day 21 of pregnancy. There was an acute increase at $12.00 \mathrm{~h}$ on day 21 to values similar to those of control rats; thereafter values remained high and not significantly different from control values (Table $\mathbf{1}$ ).

Serum prolactin concentrations measured at different times on days 19-22 in intact pregnant rats remained below $10 \mathrm{ng} \mathrm{ml}^{-1}$ until the morning of day 22 , and increased significantly thereafter. Serum progesterone concentrations remained between 40 and $70 \mathrm{ng} \mathrm{ml}^{-1}$ until the morning of day 22, and then declined progressively throughout the rest of day 22 . Ovariectomy produced an acute fall in serum progesterone concentrations, followed as expected (Vermouth and Deis, 1974) by significant increases in serum prolactin concentrations $8 \mathrm{~h}$ after surgery; prolactin concentrations remained high until $20.00 \mathrm{~h}$ on day 20 . Ovariectomy also blocked the increase in serum prolactin observed on the afternoon of day 22 in control rats.

The increases in prolactin secretion produced by the fall in serum progesterone concentrations were accompanied by significant decreases in serum $\mathrm{GH}$ concentrations with respect to intact pregnant rats and, conversely, serum $\mathrm{GH}$ concentrations increased after serum prolactin had returned to basal (less than $7.5 \mathrm{ng} \mathrm{ml}^{-1}$ ) concentrations.

\section{Effect of mifepristone administration}

Mifepristone administration induced a slight increase in serum GH concentration at $16.00 \mathrm{~h}$ on day 19 but did not modify them with respect to control rats at the other times measured until $20.00 \mathrm{~h}$ on day 20 ; serum concentrations of $\mathrm{GH}$ were significantly lower on days 21 and 22 . These rats gave birth by $08.00 \mathrm{~h}$ on day 22 . Serum progesterone concentrations started to decline in the mifepristone-treated rats by $12.00 \mathrm{~h}$ on day 20 , reaching basal values $24 \mathrm{~h}$ later, whereas prolactin concentrations were low on day 19 , but increased by $08.00 \mathrm{~h}$ on day 21 and remained high until $20.00 \mathrm{~h}$ on day 21 (Table 1). In this group of rats, serum $\mathrm{GH}$ concentrations were again significantly reduced with respect to control rats coincident with the increase in serum prolactin.

\section{Effect of tamoxifen}

The group of rats that had been given tamoxifen on days 3 and 4 of gestation showed a mean serum $\mathrm{GH}$ concentration of $15 \pm 4 \mathrm{ng} \mathrm{ml}^{-1}(n=9)$ after decapitation at $08.00 \mathrm{~h}$ on day 5 , which was significantly lower $(P<0.001$, Student's $t$ test) than the values observed at the same time in the intact pregnant rats (Fig. 1).

Daily administration of tamoxifen starting on day 17 significantly reduced serum GH concentration, except for peaks at $08.00 \mathrm{~h}$ and $16.00 \mathrm{~h}$ on day 22 (Table 1). Serum prolactin concentrations in tamoxifen-treated rats were low at all times studied and the increase seen in controls on day 21 was also blocked (Table 1). Serum progesterone concentrations were lower than those of controls at most of the times sampled, and reached values similar to those of controls on the afternoon of day 22 , and on the aftemoon of day 21 . None of the rats had given birth by $20.00 \mathrm{~h}$ on day 22 , but examination of the uterine content after decapitation on day 22 showed only dead and partially digested fetuses.

\section{Discussion}

Any study of GH concentrations in the blood should involve stress-free methods of obtaining samples since handling rats may cause a fall in the release of GH (Takahashi et al., 1971; Terry et al., 1976; Armario et al., 1984; Jurcovicova et al., 1984) and concentrations are extremely sensitive to anaesthetic. Thus, a brief $2 \mathrm{~min}$ exposure to ether has been reported to cause a significant fall in GH concentration (Schalch and Reichlin, 1966; Krulich et al., 1974; Briski et al., 1984). It is also known that major surgical procedures cause a reduction in $\mathrm{GH}$ release for two days (Obonsawin et al., 1985) and even 4 days (Eden, 1978) after the operation. However, most previous studies have been performed on male or nonpregnant female rats, and female rats seem to be less sensitive to stress in terms of $\mathrm{GH}$ release, particularly when they are pregnant (Schalch and Reichlin, 1966). An interesting finding of the present work is that pregnant female rats seem to have a shorter response to stress in terms of $\mathrm{GH}$ release than has been reported for male rats, since after ether-laparotomy, serum GH concentrations were significantly reduced for only $10 \mathrm{~min}$, whereas in male rats the duration of GH depression is longer (Eden, 1978; Obonsawin $e t$ al., 1985). This may reflect a general insensitivity of pregnant rats to stress, since prolactin secretion was unaffected by etherlaparotomy, a procedure that readily increases secretion of this hormone in virgin animals (Boehm et al., 1982). These results exclude the possibility that the modifications in hormone concentrations observed in our study were due to stress effects resulting from the methodology used.

Our results showed that a marked increase in serum GH concentrations occurred during the last 4 days of pregnancy, confirming and extending previous studies which were performed by serial sampling of individual rats on selected days of pregnancy (Saunders et al., 1976; Klindt et al., 1981; Carlsson et al., 1990). This increase may be important in the final differentiation of the mammary gland before the initiation of milk secretion and may be related to the marked increase observed in prolactin and $\mathrm{GH}$ receptors in the liver observed in the last days of pregnancy (Husman et al., 1985; Jahn et al., 1991).

Regulation of GH release seems to be different to that of prolactin at the end of gestation. The increase observed on the last days of pregnancy could be a consequence of increased oestrogen secretion seen in rats from day 19 (Shaikh, 1971), as oestrogens have been shown to stimulate $\mathrm{GH}$ production by the pituitary (Simard et al., 1986; Armario et al., 1984). The high serum GH concentrations found on the morning of day 5 of pregnancy may also be a product of stimulation by oestrogens secreted on this day (Shaikh, 1971), that are necessary for implantation, since the high $\mathrm{GH}$ concentrations were inhibited by prior administration of tamoxifen. Furthermore, tamoxifen 
administration in the last days of pregnancy produced significant decreases in serum GH and prolactin concentrations.

The changes in prolactin secretion followed the previously described increases observed after the progesterone fall induced by ovariectomy (Vermouth and Deis, 1974). Mifepristone administration did not induce an immediate increase in prolactin secretion (Deis et al., 1989), but prolactin concentrations rose after $48 \mathrm{~h}$ as a consequence of the delayed fall in serum progesterone concentrations. Our results also indicate a role for oestrogens in the increase in prolactin secretion on day 22 (when serum progesterone concentrations are low; Bussmann and Deis, 1979; Nicholas and Hartmann, 1981), as ovariectomy, as well as tamoxifen administration, completely abolished this rise.

A potential stimulatory action for oestrogens and progesterone on the maintenance of luteal progesterone production in late pregnancy is indicated since both anti-hormones advanced the fall in serum progesterone. A role for both steroid hormones in the maintenance of luteal function in rats has already been described in early and mid-pregnancy (Gibori and Keyes, 1978, 1980; Rothchild, 1980; Kawano et al., 1988; Singh et al., 1988), and our results extend this role to the end of pregnancy.

There appears to be an inverse relationship between prolactin and GH secretion on the last days of pregnancy. In intact, pregnant rats the increase in $\mathrm{GH}$ secretion occurred 3 days before the release of prolactin, and when prolactin secretion increased, serum GH concentrations had already fallen. The increases in prolactin secretion observed after ovariectomy or mifepristone treatment were accompanied by decreases in serum $\mathrm{GH}$, which returned to control concentrations when prolactin concentrations diminished. The reciprocal relationship between prolactin and $\mathrm{GH}$ was observed independent of experimental procedure or progesterone concentrations, except for the tamoxifen-treated rats, in which both hormones were depressed, indicating a stimulatory action of oestrogens for both hormones. The stimulatory action of oestrogens on $\mathrm{GH}$ release may be evident only in the presence of low concentrations of prolactin. In contrast, any action of progesterone seems to be mediated through its regulation of prolactin secretion.

It is known that many factors regulate $\mathrm{GH}$ secretion, but according to our results progesterone does not directly regulate $\mathrm{GH}$ release and oestrogen may not be the main factor involved. The inverse relationship between GH and prolactin secretion means that both hormones cannot be released simultaneously. The inhibitory effect of hyperprolactinaemia on $\mathrm{GH}$ secretion in female (Esquifino et al., 1987a) and male rats (Esquifino et al., 1987b) and in women (Andersen and Tabor, 1982; Ho et al., 1985) has been reported already.

This work was supported by a grant (PID 9036/01) from the Consejo Nacional de Investigaciones Cientificas y Tecnicas (CONICET), Argentina. The authors are indebted to F. E. Guinazu de Di Nasso for her excellent technical assistance. We thank A. F. Parlow and the NIADDK for the rat GH and prolactin kits.

\section{References}

Andersen AN and Tabor A (1982) Prl, TSH, GH and LH responses to metoclopramide and breast-feeding in normal and hyperprolactinaemic women Acta Endocrinologica 100 177-183
Armario A, Castellanos JM and Balash J (1984) Dissociation between corticosterone and growth hormone adaptation to chronic stress in the rat Hormone and Metabolic Research 16 142-145

Boehm N, Plas-Roser S, Lazarus C and Aron C (1982) Influence of blood removal under ether anaesthesia on the release of prolactin during the oestrous cycle of the rat. Involvement of the ovaries Acta Endocrinologica 99 179-186

Briski KP, Quigley K and Meites J (1984) Counteraction by morphine of stressinduced inhibition of growth hormone release in the rat Proceedings of the Society for Experimental Biology and Medicine 177 137-142

Bussmann LE and Deis RP (1979) Studies concerning the hormonal induction of lactogenesis by prostaglandin $F_{2 a}$ in pregnant rats Journal of Steroid Biochemistry 11 1485-1489

Carlsson L, Eden S and Jansson J-O (1990) The plasma pattern of growth hormone in conscious rats during late pregnancy Joumal of Endocrinology 124 191-198

Crowley W, Terry LC and Johnson MD (1982) Evidence for the involvement of central epinephrine systems in the regulation of luteinizing hormone, prolactin, and growth hormone release in female rats Endocrinology 110 1102-1107

Deis RP, Carrizo DG and Jahn GA (1989) Suckling-induced prolactin release potentiates mifepristone-induced lactogenesis in pregnant rats Joumal of Reproduction and Fertility 87 147-153

Eden S (1978) The secretory pattern of growth hormone. An experimental study in the rat Acta Physiologica Scandinavica Supplement 458 I-54

Eden S (1979) Age- and sex-related differences in episodic growth hormone secretion in the rat Endocrinology 105 555-560

Eden S, Bolle P and Modigh K (1979) Monoaminergic control of episodic growth hormone secretion in the rat: effects of reserpine, $\alpha$-methyl-p-tyrosine, p-chlorophenylalanine, and haloperidol Endocrinology 105 523-529

Esquifino Al, Vilanua MA and Agrasal C (1987a) Possible role of prolactin in growth regulation Revista Espanola de Fisiologia 43 455-462

Esquifino AI, Fernandez-Ruiz JJ, Cebeira M, Agrasal C, Tresguerres JAF and Ramos JA (1987b) Effect of experimentally induced hyperprolactinemia on growth hormone secretion Revista Espanola de Fisiologia 43 463-468

Gibori G and Keyes L (1978) Role of intraluteal estrogen in the regulation of the rat corpus luteum during pregnancy Endocrinology 102 1176-1182

Gibori G and Keyes L (1980) Luteotrophic effect of estrogen in the early pregnancy in the rat Endocrinology $1061584-1588$

Hall TR, Harvey S and Scanes CG (1986) Control of growth hormone secretion in the vertebrates: a comparative survey Comparative Biochemistry and Physiology 84A 231-253

Ho KY, Smythe GA and Lazarus L (1985) Enhanced hypothalamic dopaminergic inhibition of LH, TSH and GH release in patients with pathological hyperprolactinaemia Acta Endocrinologica 108 289-296

Ho KY, Evans WS, Blizzard RM, Veldhuis JD, Merriam GR, Samojlik E, Furlanetto E, Ropol AD, Kaiser DL and Thorner MO (1987) Effects of sex and age on the 24 hour profile of growth hormone secretion in man: importance of endogenous estradiol concentration Journal of Clinical Endocrinology and Metabolism 64 51-58

Husman B, Andersson G, Norstedt G and Gustafsson J-A (1985) Characterization and subcellular distribution of the somatogenic receptor in rat liver Endocrinology 116 2605-2611

Jahn GA and Deis RP (1987) A possible dual regulation of prolactin release by the serotoninergic system in pro-oestrous and late pregnant rats: role of the ovarian hormones Journal of Endocrinology 112 367-374

Jahn GA and Deis RP (1988) Effect of serotonin antagonists on prolactin and progesterone secretion. Evidence that the stimulatory and inhibitory actions of serotonin upon prolactin release may be mediated through different receptors Joumal of Endocrinology $117415-422$

Jahn GA and Deis RP (1991) The involvement of the adrenergic system on the release of prolactin and lactogenesis at the end of pregnancy in the rat Journal of Endocrinology 129 343-350

Jahn GA, Rastrilla AM and Deis RP (1987) Modificaciones de los niveles sericos de GH durante la prenez en la rata Medicina 47 Abstract 365

Jahn GA, Edery M, Belair L and Djiane J (1991) Prolactin gene expression in rat mammary gland and liver during pregnancy and lactation Endocrinology 128 2976-2984

Jansson JO, Ekberg S, Isaksson O and Eden S (1984) Influence of gonadal steroids on age- and sex-related secretory patterns of growth hormone in the rat Endocrinology 114 1287-1294

Jansson JO, Eden S and Isaksson O (1985) Sexual dimorphism in the control of growth hormone secretion Endocrine Reviews 6 128-150 
Jurcovicova J, Vigas M, Klir P and Jezova D (1984) Response of prolactin growth hormone and corticosterone secretion to morphine administration or stress exposure in Wistar-AVN and Long Evans rats Endocrinologia Experimentalis 18 209-214

Kawano T, Okamura H, Tajima C, Fukuma K and Hatabuchi H (1988) Effect of RU 486 on luteal function in the early pregnant rat Joumal of Reproduction and Fertility 83 279-285

Klindt J, Robertson MC and Friesen HG (1981) Secretion of placental lactogen, growth hormone, and prolactin in late pregnant rats Endocrinology 109 1492-1495

Krulich L, Hefco E, Iliner P and Read CB (1974) The effects of acute stress on the secretion of $\mathrm{LH}, \mathrm{FSH}$, prolactin and $\mathrm{GH}$ in the normal male rat, with comments on their statistical evaluation Neuroendocrinology 16 293-311

Leung FC, Chen HT, Verkaik SJ, Steger RW, Peluso JJ, Campbell GA and Meites J (1980) Mechanism(s) by which adrenalectomy and corticosterone influence prolactin release in the rat Joumal of Endocrinology 87 131-140

Martin JB, Duran D, Gurd W, Faille G, Audet J and Brazeau P (1978) Neuropharmacological modulation of episodic growth hormone and prolactin secretion in the rat Endocrinology 102 106-113

Nagy G, Kacsoh B, Kanyicska B, Toth BE and Korausz E (1986) Separation and suckling-induced changes in serum growth hormone levels of lactating rats and their pups Endocrinologia Experimentalis 20 217-222

Nakagawa K, Akikawa K, Matsubara M, Kubo M, Ishizuka T and Obara T (1987a) Biphasic effects of dexamethasone on growth hormone release in vitro Endocrinologia Japonica 34 947-953

Nakagawa K, Ishizuka T, Obara T, Matsubara M and Akikawa K (1987b) Dichotomic action of glucocorticoids on growth hormone secretion Acta Endocrinologica 116 165-171

Nicholas PR and Hartmann PE (1981) Progesterone control of the initiation of lactose synthesis in the rat Australian Journal of Biological Sciences 34 435-443

Obonsawin MC, Shin SH and Arrowsmith J (1985) Surgery depresses pulsatile growth hormone release in rats for up to 2 days Acta Endocrinologica 110 $42-45$

Rothchild I (1980) The regulation of the mammalian corpus luteum Recent Progress in Hormone Research 37 183-298

Sar M and Meites J (1969) Effects of suckling on pituitary release of prolactin, GH and TSH in postpartum lactating rats Neuroendocrinology 425-31
Saunders A, Terry LC, Audet J, Brazeau P and Martin JB (1976) Dynamic studies of growth hormone and prolactin secretion in the female rat Neuroendocrinology 21 193-203

Schalch DS and Reichlin S (1966) Plasma growth homrone concentration in the rat determined by radio-immunoassay: influence of sex, pregnancy, lactation, anesthesia, hypophysectomy and extracellular pituitary transplants Endocrinology $79275-280$

Shaikh A (1971) Estrone and estradiol levels in ovarian venous blood from rats during the estrous cycle and pregnancy Biology of Reproduction 5 297-307

Simard J, Hubert JF, Hosseinzadeh T and Labrie $\mathbf{F}$ (1986) Stimulation of growth hormone release and synthesis by estrogens in rat anterior pituitary cells in culture Endocrinology 119 2004-2011

Singh G, Singh MM, Maitra SC, Elger W, Kalra V, Upadhyay SN, Chowdhury SR and Kamboj VP (1988) Luteolytic action of two antiprogestational agents (RU 486 and ZK-93734) in the rat Journal of Reproduction and Fertility 83 73-83

Snedecor GW and Cochran WG (1967) Statistical Methods. Iowa State University Press

Takahashi K, Daughaday WH and Kipnis DM (1971) Regulation of immunoreactive growth hormone secretion in male rats Endocrinology $\mathbf{8 8}$ 909-917

Tannenbaum GS and Martin JB (1976) Evidence for an endogenous ultradian rhythm governing growth hormone secretion in the rat Endocrinology 98 562-570

Terry LC, Willoughby JO, Brazeau P, Martin JB and Patel Y (1976) Antiserum to somatostatin prevents stress-induced inhibition of growth hormone secretion in the rat Science $192565-567$

Vermouth NT and Deis RP (1972) Prolactin release induced by prostaglandin $F_{2 a}$ in pregnant rats Nature 238 248-250

Vermouth NT and Deis RP (1974) Prolactin release and lactogenesis after ovariectomy in pregnant rats: effect of ovarian hormones Journal of Endocrinology 63 13-20

Willoughby JO and Day TA (1981) Central catecholamine depletion: effects on physiological growth hormone and prolactin secretion Neuroendocrinology 32 $65-69$

Willoughby JO, Menadue MF and Liebelt H (1987) Activation of serotonin receptors in the medial basal hypothalamus stimulates growth hormone secretion in the unanesthetized rat Brain Research 404 319-322 